\title{
Effect of hormone secretory syndromes on neuroendocrine tumor prognosis
}

\author{
Wouter T Zandee, Kimberly Kamp, Roxanne C van Adrichem, Richard A Feelders \\ and Wouter $\mathbf{W}$ de Herder
}

Department of Internal Medicine, Sector Endocrinology, ENETS Centre of Excellence, Erasmus MC, Rotterdam, the Netherlands
Correspondence should be addressed to W T Zandee Email w.zandee@erasmusmc.nl

\begin{abstract}
The treatment of hormone hypersecretory syndromes caused by neuroendocrine tumors (NETs) can be a major challenge. NETs originating from the small intestine often secrete serotonin causing flushing, diarrhea and valve fibrosis, leading to dehydration or heart failure in severe cases. NETs from the pancreas can secrete a wider variety of hormones, like insulin, glucagon and gastrin leading to distinct clinical syndromes. Historically mortality in patients with functioning NETs was high due to the complications caused by the hypersecretion of hormones. This has been reduced with several drugs: protonpump inhibitors decrease acid secretion caused by gastrinomas. Somatostatin analogs can inhibit the secretion of multiple hormones and these are now the cornerstone for treating patients with a gastroenteropancreatic NET. However, peptide receptor radionuclide therapy (PRRT) with radiolabeled somatostatin analogs and everolimus can also decrease symptoms of hypersecretion and increase progression-free survival. Several factors affect the survival in patients with a functioning NET. Complications of hypersecretion negatively impact survival; however, secretion of hormones is also often a sign of a well-differentiated NET and due to the symptoms, functioning NETs can be detected in an earlier stage suggesting a positive effect on prognosis. The effect on survival is also dependent on the type of hormone being secreted. This review aims to study the effect of hormone secretion on the prognosis of NETs with the contemporary treatments options available today.
\end{abstract}
Key Words
- neuroendocrine tumor
- hormone secretion
- prognosis
- carcinoid syndrome

Endocrine-Related Cancer (2017) 24, R261-R274

\section{Introduction}

Neuroendocrine tumor (NETs) are often best known for causing hypersecretory syndromes, through the hormones they secrete, which is mainly determined by the cell of origin (Kaltsas et al. 2004). More than 15 individual neuroendocrine cell types have been identified, and they all secrete different hormones, causing different kinds of syndromes (Kidd et al. 2015). These syndromes of hormone excess are diagnosed when the clinical presentation fits a certain syndrome, and this is confirmed by demonstrating that corresponding hormone levels are elevated (Kaltsas et al. 2004). When patients present without a specific syndrome or without elevated hormone levels, they are diagnosed with a non-functioning, or nonsyndromic, NET. Small intestinal NETs almost exclusively secrete serotonin, and when metastasized causing the carcinoid syndrome with symptoms of flushing, diarrhea

Published by Bioscientifica Ltd. 
Table 1 Overview of the most common neuroendocrine tumor syndromes: origin and incidence.

\begin{tabular}{|c|c|c|c|c|}
\hline Hormone & Cell & Location & Tumor & Incidence (per million) \\
\hline Serotonin & $\mathrm{EC}$ & $\begin{array}{l}\text { Stomach, pancreas, duodenum, small } \\
\text { intestine, colon, appendix, rectum }\end{array}$ & Carcinoid & $0.2-0.6$ \\
\hline Insulin & B & Pancreas & Insulinoma & $1-3$ \\
\hline Gastrin & G & Duodenum & Gastrinoma & $0.5-2$ \\
\hline Glucagon & a & Pancreas & Glucagonoma & $0.02-0.06$ \\
\hline VIP & VIP & Pancreas, sympathetic ganglia & VIPoma & $0.05-0.2$ \\
\hline ACTH & Various & Lung, adrenals, thyroid, pancreas & ACTHoma & Rare \\
\hline PTH & Various & Lung, pancreas & PTH-like-oma & Rare \\
\hline Somatostatin & $\mathrm{D}$ & $\begin{array}{l}\text { Pancreas, stomach, duodenum, colon, } \\
\text { rectum, appendix }\end{array}$ & Somatostatinoma & Rare \\
\hline
\end{tabular}

and carcinoid heart disease. Pancreatic NETs show a much larger variation in hormonal secretion and are capable to secrete insulin, glucagon, gastrin and other hormones (Table 1). Arising from different neuroendocrine cell types and causing different symptomology, survival differs between these syndromes as well. Strong predictors of survival are the grade, based on the Ki67-index, and the WHO/ENETS staging (Klimstra et al. 2010). The biomarkers chromogranin A and neuron-specific enolase are predictors of survival as well. Serum chromogranin $\mathrm{A}$ is a marker for tumor burden, and elevated serum chromogranin A is associated with a shorter survival (Arnold et al. 2008, Han et al. 2015). Neuron-specific enolase was long thought to be a predictive biomarker not only in poorly differentiated NET and small cell carcinomas but also in low-grade NETs, an elevated serum neuron-specific enolase is a negative predictor of survival (van Adrichem et al. 2015). The influence of hormone hypersecretion on survival in patients with NETs remains unclear.

Historically, the slow growth of NETs often resulted in survival not being limited by tumor burden but by complications caused by the hypersecretion of hormones (Thorson et al. 1954). However, many steps have been made in treatment of these patients mainly with the discovery of somatostatin and the subsequent development of octreotide, allowing the inhibition of hormone secretion and thus reduction of clinical symptoms and morbidity (Kvols et al. 1986). Long-acting somatostatin analogs can now be administered only once a month vs three times daily for octreotide subcutaneously, once more improving quality of life for patients (Rinke et al. 2009, Caplin et al. 2014). Also peptide receptor radionuclide therapy (PRRT) with radiolabeled somatostatin analogs and tumor-targeted therapy (everolimus and sunitinib) are now available for the treatment of metastatic NETs (Kwekkeboom et al. 2008, Raymond et al. 2011, Yao et al. 2016). Also, simply decreasing acid secretion with PPIs in gastrinoma patients strongly reduces the incidence of peptic ulcer disease (Hirschowitz et al. 2005). It is without question that before all these contemporary options were available, patients with a hypersecreting NET had a worse prognosis, due to the complications of hormone hypersecretion. On the other hand, hormone secretion is often a sign of a well-differentiated NET with, theoretically, a better survival (Wang et al. 2011). Also symptoms caused by the secreting NET could allow for detection of the NET in an earlier stage. In this review, we will study available literature, questioning the influence of hormonal secretion on NET prognosis in the current era, focusing on NETs originating from the pancreas and the gut.

\section{Serotonin and the carcinoid syndrome}

The histological diagnosis of a 'Karzinoide' was first described early in the twentieth century and the first cases of carcinoid syndrome were described from 1927 onward (Oberndorfer 1907, Postma 1927, Cassidy 1930). Patients presented with diarrhea and flushing and postmortem examination revealed tumors in the ileum, liver metastases and tricuspid valve stenosis, but the link connecting these findings remained unknown (Cassidy 1931, Scholte 1931). In the 1950s, several discoveries were made, significantly advancing the knowledge of the carcinoid syndrome. Serotonin was identified by Page and in a case series published in 1954, Thorson and coworkers linked flushing, diarrhea and right-sided heart failure to carcinoids in the small intestine and identified serotonin secretion as a possible cause of the syndrome (Page 1954, Thorson et al. 1954). Survival varied from over ten years when patients first complained of abdominal pain or flushing, to weeks when presenting with heart failure.

Nowadays the carcinoid syndrome is a well-known entity. Text books clearly describe the symptomatology of flushing, diarrhea, bronchospasm and eventually 
valvular heart disease, but this typical presentation is rare (Pape et al. 2008). It is a clinical diagnosis, made when these symptoms are present and when there is evidence for increased serotonin secretion. Serotonin levels can be measured in several ways, but excretion of 24-h urinary 5-hydroxyindoleacetic acid (5-HIAA), the degradation product of serotonin, is most validated in diagnosis and follow-up of NETs (O'Toole et al. 2009). In the near future, plasma 5-HIAA will probably play a more prominent role (Tellez et al. 2013). Occasionally, NETs from organs like the lung, ovaries and pancreas can cause the carcinoid syndrome, but it is most frequently associated with NETs from the embryological midgut and so our knowledge on the carcinoid syndrome is mainly based on these tumors. The midgut NETs arise from enterochromaffin cells in the intestine and when the tumor is limited to the abdomen (ENETS Stage I-IIIb), secreted serotonin is efficiently metabolized in the liver and therefore localized disease rarely causes symptoms. But liver, bone and retroperitoneal or distant node metastases as well as lung and ovary primaries directly secrete serotonin and other mediators into the systemic circulation, and this causes the carcinoid syndrome (Grozinsky-Glasberg et al. 2015). This factor is of great importance because this influences incidence of carcinoid syndrome in different centers and it confounds the influence of the carcinoid syndrome on prognosis.

In epidemiological studies, incidence of midgut NETs varies between regions. Current incidence is estimated to be around $0.3-1.1$ cases annually per 100,000 persons and seems to be increasing in recent years (Modlin et al. 2003, Yao et al. 2008, Ellis et al. 2010, Landerholm et al. 2010). Whether this is due to a true increase in incidence or to increased imaging procedures or both remains to be elucidated. The incidence of the carcinoid syndrome in these patients is highly dependent on the selected population. In nationwide surveys or cancer registries, $3-19 \%$ of patients with a small intestinal NET have the carcinoid syndrome, but incidence has been reported as high as $71 \%$ in specialized centers, treating more patients with advanced disease (Bax et al. 1996, Janson et al. 1997, Soga 2003, Niederle et al. 2010, Halperin et al. 2017).

When surgery, chemotherapy and radiotherapy were the only options for the treatment of metastatic small intestinal NETs, the prognosis was mediocre and overall 5 -year survival rate was approximately $50-60 \%$ for all stages combined (Barclay \& Schapira 1983, Zollinger 1986). Also patients with a functioning NET had a shorter median survival. In a study by Norheim and coworkers in 1987, median survival from the time of histologic diagnosis was 14 years but 8 years from the time of onset of the carcinoid syndrome (Norheim et al. 1987). With new options for treatment becoming available for patients with a NET in the past two decades, there has been a large improvement in the quality of life and prognosis.

Patients with the carcinoid syndrome almost exclusively have extensive disease but curative surgery should still be the first option to consider. Unfortunately, this is not feasible in many patients and palliative therapy should be started to control symptoms and tumor growth (Pavel et al. 2016). This is best achieved with a somatostatin analog (SSA). The first studies with these drugs revealed significant reduction of symptoms by reducing serotonin secretion, measured with 24-h urinary 5-HIAA excretion (Modlin et al. 2010). Subsequently, this was confirmed in randomized controlled trials. Two well-known, landmark trials have shown that SSAs increase progression-free survival (PFS). Lanreotide was found to increase PFS in patients with non-functioning neuroendocrine tumors (gastrinomas were included) (Caplin et al. 2014). In the PROMID trial, median PFS increased from 6.0 months with placebo to 14.3 months when treated with octreotide LAR and in this study $36 \%$ of patients had the carcinoid syndrome at baseline (Rinke et al. 2009). Treatment effect was equal in patients with a functioning or non-functioning tumor and while PFS was shorter in patients with a functioning tumor, this did not reach significance (HR 1.38; 95\% CI: 0.81-2.37). Second-line options include peptide receptor radionuclide therapy (PRRT) and everolimus (van der Zwan et al. 2015). PRRT with ${ }^{177} \mathrm{Lu}$-DOTAtate resulted in a longer PFS in patients with midgut NETs. After 20 months, $65.2 \%$ of these patients were without tumor progression (RECIST) as compared to $10.8 \%$ in the control group using a doubled dose $(60 \mathrm{mg})$ of octreotide LAR every 4 weeks in the NETTER-1-study (HR for progression 0.21; 95\% CI: 0.13-0.33) (Strosberg et al. 2017). Furthermore, PRRT can reduce symptoms (pain, fatigue and carcinoidrelated symptoms) in selected patients (Kam et al. 2012, Seregni et al. 2013). Everolimus is specifically tested in patients with the carcinoid syndrome, but no direct comparison was made with non-functioning tumors, as these were studied in a different trial (Pavel et al. 2011, Yao et al. 2016). Compared to octreotide LAR alone, treatment with everolimus resulted in a larger reduction of urinary 5-HIAA excretion in the RADIANT-2 trial, but the effects on symptoms of carcinoid syndrome or quality of life were not studied (Pavel et al. 2011). With all these contemporary medical options, 5 year survival for stage IV midgut NETs has been described as being $54 \%$ to as

Published by Bioscientifica Ltd 
Table 2 Overall survival and peri-operative mortality in surgical series on carcinoid heart disease.

\begin{tabular}{|c|c|c|c|}
\hline & Overall survival & Peri-operative mortality & Number of patients \\
\hline Robiolio et al. (1995) & 5 year: $25 \%$ & $62.5 \%(<1995)$ & 8 \\
\hline Moller et al. (2005) & Median survival: 2.6 years & $\begin{array}{r}25 \%(1981-1989) \\
9 \%(1995-2000)\end{array}$ & $\begin{array}{l}12 \\
43\end{array}$ \\
\hline Mokhles et al. (2012) & 5 year: $43 \%$ & $5.7 \%(1993-2010)$ & 19 \\
\hline Bhattacharyya et al. (2010) & 2 year: $44 \%$ & $18 \%(2006-2010)$ & 22 \\
\hline \multirow[t]{4}{*}{ Connolly et al. (2015) } & 5 year: $35 \%$ & $20 \%(<1990)$ & 10 \\
\hline & & $16.4 \%(1990-1999)$ & 61 \\
\hline & & $7.2 \%(2000-2009)$ & 97 \\
\hline & & $3.7 \%(2010-2012)$ & 27 \\
\hline Edwards et al. (2016) & 2 year: $69 \%$ & $13 \%(2005-2015)$ & 32 \\
\hline
\end{tabular}

Peri-operative mortality: mortality rate the first 30 days after surgery for carcinoid heart disease.

high as $84.8 \%$ (Quaedvlieg et al. 2001, Yao et al. 2008, Jann et al. 2011).

Treatment of carcinoid heart disease has also vastly improved. In the nineties over a quarter of patients died of carcinoid heart disease, and this was almost 50\% of disease-related death (Makridis et al. 1997). There is strong evidence that serotonin plays an important role, so reduction of secretion with SSAs and telotristate could potentially reduce the risk of developing carcinoid heart disease, but no studies, with these drugs, show the effect on the incidence of carcinoid heart disease or overall survival due to the slow progressive character of NETs (Pavel et al. 2015). Also increasing experience in valve replacement surgery in patients with carcinoid heart disease has resulted in a sharp reduction of peri-operative mortality to approximately $4-10 \%$ with an overall survival approaching that of non-syndromic patients (Table 2). However, this might be biased by selecting patients for surgery in an earlier stage. Regular screening on carcinoid heart disease and optimal timing of cardiac valve replacement are important factors that determine the ultimate outcome.

Altogether treatment of the carcinoid syndrome has clearly advanced and with that, its influence on prognosis is diminishing. Historically symptomatic patients, on average, have a shorter survival. Simply looking at the urinary 24-h 5-HIAA excretion indeed shows that patients with elevated excretion have a shorter survival (Turner $e t$ al.
2006, Formica et al. 2007, van der Horst-Schrivers et al. 2007). But after correction for metastases (ENETS Stage IV) and tumor burden (with chromogranin A), urinary 5-HIAA excretion is no longer a predictor for survival (Janson et al. 1997, Zandee et al. 2016). Few studies have purely compared survival of functional and non-functional midgut NETs. Often urinary 5-HIAA excretion is used as marker for the carcinoid syndrome, but this does not always correlate with the clinical symptoms, which are used to define carcinoid syndrome (Zuetenhorst et al. 2004). Only limited number of studies have been published on the effect of carcinoid syndrome on survival (on the basis of clinical symptoms) (Table 3). Halperin and coworkers and Janson and coworkers demonstrated a shorter survival for functional NETs (HR 1.10 and HR 2.9) in a respective cohort-study (SEER database) and a center-based study (Janson et al. 1997, Halperin et al . 2017). However, after correction for liver burden and other biomarkers by Janson and coworkers, survival no longer differs between patients with and without carcinoid syndrome. Halperin and coworkers could not correct for tumor burden, due to the limitations in the data collection. In contrast to these studies, two other studies did not demonstrate a significant influence of carcinoid syndrome on survival (Formica et al. 2007, Jann et al. 2011).

Much less is known of the influence of carcinoid syndrome in pancreas NETs because this is a rare phenomenon, occurring in about only $1 \%$ of pNETs (Modlin et al. 2005, Soga 2005, Bilimoria et al. 2007,

Table 3 Overall survival in patients with carcinoid syndrome vs non-functional midgut NET.

\begin{tabular}{|c|c|c|c|c|c|}
\hline & Hazard ratio $(95 \% \mathrm{Cl})$ & 2-year survival & 5-year survival & 10-year survival & \\
\hline \multicolumn{6}{|c|}{ Survival in carcinoid syndrome (functional vs non-functional) } \\
\hline Jann et al. (2011) & & $96.9 \%$ vs $97.6 \%$ & $85.6 \%$ vs $93.7 \%$ & $64.2 \%$ vs $79.7 \%$ & NS \\
\hline Janson et al. (1997) & $2.9(1.4-6.0)$ & & & & NS in multivariate \\
\hline Formica et al. (2007) & $1.18(0.7-1.9)$ & & & & NS \\
\hline Halperin et al. (2017) & $1.10(1.02-1.20)$ & & & & $\begin{array}{l}\text { No correction for } \\
\text { tumor burden }\end{array}$ \\
\hline \multicolumn{6}{|l|}{ NS: not significant. } \\
\hline $\begin{array}{l}\text { http://erc.endocrinology-journ } \\
\text { DOI: 10.1530/ERC-16-0538 }\end{array}$ & \multicolumn{2}{|c|}{$\begin{array}{r}\text { (c) } 2017 \text { Society for Endocrinology } \\
\text { Printed in Great Britain }\end{array}$} & \multicolumn{3}{|c|}{ Published by Bioscientifica Ltd. } \\
\hline
\end{tabular}


La Rosa et al. 2011). However, its influence on survival seems to mimic that of the midgut NETs. Serotonin secretion has a negative influence on survival, but it occurs mainly in patients with metastasized disease and bulky tumors. After correcting for this fact, serotonin secretion no longer influenced survival (Zandee et al. 2017).

It is clear that the mortality of the carcinoid syndrome is decreasing due to reduction of serotonin secretion with potent drugs and improved valve surgery. At the same time, survival has increased for both functional and non-functional NETs, due to the anti-proliferative effect of SSAs, tumor-targeted therapy and PRRT. Unfortunately mortality for patients with the carcinoid syndrome remains relatively high, but this is probably due to extensive tumor load and not due to the effects of serotonin secretion.

\section{Pancreatic neuroendocrine tumors}

Neuroendocrine tumors originating from the pancreas can produce a wide variety of hormones like insulin and glucagon. Currently, it is not recommended to screen for hormone secretion unless symptoms fit a certain functioning tumor syndrome (Falconi et al. 2016). Unlike the carcinoid syndrome in patients with midgut tumors, pNETs do not need to metastasize before symptoms arise.
For example, $90 \%$ of insulinomas are smaller than $4 \mathrm{~cm}$ and limited to the pancreas at diagnosis (Mehrabi et al. 2014). Non-functioning pNETs mostly present either with an incidentaloma or with abdominal pain, and it is suggested that thereby these patients present more frequently with advanced disease (Cheema et al. 2012, Crippa et al. 2014).

In many studies, comparing survival of nonfunctioning pNETs with their functional counterpart, functional pNETs are described as a group with no subselection for the type of hormone. Therefore, we will first discuss these studies, followed by a focus on the prevalent syndromes.

After diagnosis of a pNET according to guidelines, curative surgery is the first consideration (Falconi et al. 2016). A small number of studies are published on observation only, for non-functioning pNETs smaller than $2 \mathrm{~cm}$. Results are promising, but no long-term data is available yet (Sadot et al. 2016). Due to the symptomology of functioning pNETs observation is often not preferred except for selected patients with a gastrinoma. Only Cubilla and coworkers report a worse prognosis for patients with functional tumors but values for significance are not reported (Cubilla \& Hajdu 1975). Most surgical series show a better prognosis for patients with a functional tumor, but after correction for other

Table 4 Reported 5-year survival, comparing functional and non-functional pancreatic neuroendocrine tumors.

\begin{tabular}{|c|c|c|c|c|c|c|}
\hline & \multicolumn{3}{|c|}{ 5-year survival (\%) } & \multirow{2}{*}{$\begin{array}{c}\text { Number of } \\
\text { patients }\end{array}$} & \multirow[b]{2}{*}{$\begin{array}{l}\text { Functioning } \\
\text { (insulinoma \%) }\end{array}$} & \multirow[b]{2}{*}{ Remarks } \\
\hline & Functional (\%) & Non-functional (\%) & $P$ value & & & \\
\hline \multicolumn{7}{|l|}{ Surgical series } \\
\hline Phan et al. (1998) & 77 & 52 & 0.025 & 125 & $64(55)$ & $\begin{array}{l}\text { Surgical, } P=0.14 \text { in } \\
\text { metastatic NET }\end{array}$ \\
\hline Sarmiento et al. (2002) & 100 & 70 & 0.08 & 29 & $9(33.3)$ & Surgical \\
\hline Jarufe et al. (2005) & 82.5 & 55.0 & 0.41 & 44 & $24(66.6)$ & $\begin{array}{l}\text { Surgical curative } \\
\quad(50 \% \geq \text { Stage IIIb) }\end{array}$ \\
\hline Vagefi et al. (2007) & 89 & 78 & 0.16 & 168 & $70(33.3)$ & Surgical \\
\hline Bilimoria et al. (2008) & 67.7 & 60.0 & $<0.001$ & 3851 & $619(20.7)$ & $\begin{array}{c}\text { Surgical series all stages, } \\
P=0.03 \text { in multivariate }\end{array}$ \\
\hline Gao et al. (2010) & 77 & 74 & 0.225 & 112 & $47(60.0)$ & $\begin{array}{l}\text { Surgical treatment all } \\
\text { stages }\end{array}$ \\
\hline Partelli et al. (2015) & 71 & 57 & 0.148 & 166 & $15(26.7)$ & $\begin{array}{l}\text { Surgery stage IV, including } \\
\text { palliative and no } \\
\text { resection }\end{array}$ \\
\hline \multicolumn{7}{|l|}{ Cohort studies } \\
\hline Wang et al. (2011) & 96.8 & 71.6 & 0.008 & 93 & 39 (71.7) & $\begin{array}{l}\text { DSS, all stages, center } \\
\text { based } \\
\text { Not significant in } \\
\text { multivariate }\end{array}$ \\
\hline Martin-Perez et al. (2013) & 83.6 & 73.4 & 0.185 & 483 & $171(44.4)$ & Population based \\
\hline Chu et al. (2002) & 48 & 30 & 0.27 & 55 & $21(28.5)$ & All stages \\
\hline Halfdanarson et al. (2008) & 47.6 & 31.3 & $<0.001$ & 1483 & $137(27.0)$ & $\begin{array}{l}\text { All stages, SEER database } \\
P=0.004 \text { in multivariate }\end{array}$ \\
\hline $\begin{array}{l}\text { http://erc.endocrinology-journals.org } \\
\text { DOI: 10.1530/ERC-16-0538 }\end{array}$ & () 201 & $\begin{array}{l}7 \text { Society for Endocrinolo } \\
\text { Printed in Great Brita }\end{array}$ & & & & \\
\hline
\end{tabular}


factors like stage, often no significant difference is found (Table 4 and 5). Phan and coworkers have reported a higher probability of survival for functional pNETs, but at baseline, patients with non-functional NETs had, on average, a larger primary tumor and more often metastatic disease. A subgroup analysis in malignant NETs (node or hepatic metastases) showed no significant difference in survival for functionality. Only Bilimoria and coworkers report a significant difference in uni- and multivariate analyses between functional and non-functional pNETs in patients undergoing pancreatic surgery, including metastasized pNETs (Bilimoria et al. 2008). In the subgroup analysis of this study, a better prognosis for gastrinomas is reported (HR 0.52, 95\% CI: 0.30-0.92), while other syndromes did not have a significant longer survival. Several center-wide or cohort studies report a better survival for functional tumors (Ekeblad et al. 2008, Halfdanarson et al. 2008, Wang et al. 2011, Yang et al. 2015). Including all stages of disease and all types of treatment, functional tumors have a better prognosis; however, in multivariate analyses, only Halfdanarson and coworkers report higher survival rates for functional NETs (HR 0.71; 95\% CI: 0.57-0.89). Wang and coworkers have studied 93 pNET patients and reported a higher five-year survival in functioning NETs. However, at baseline, the non-functioning NETs were significantly more poorly differentiated and were also more often metastasized to lymph nodes. Ekeblad and coworkers and Yang and coworkers also reported higher survival probabilities in functional NETs, but in multivariate analyses, correcting for stage and differentiation, this was no longer significant. So in this broad spectrum, patients with a functional pNET have a better prognosis than their non-functioning counterparts; however, this is often biased by stage and differentiation. Correction for these factors almost always results in comparable prognosis for functional and non-functional pNETs, so once again, the difference in prognosis between functioning and non-functioning NETs is probably explained by tumor burden and differentiation and not by hormone secretion.

\section{Insulinomas}

The first patient with the typical presentation of an insulinoma was described in 1927 by Wilder (Wilder et al. 1927). This patient turned out to have a malignant insulinoma with liver metastases. Insulinomas present mainly with hypoglycemia resulting in episodes of confusion, loss of consciousness, sweating or dizziness and body weight increases (Stefanini et al. 1974, Fajans \& Vinik 1989). The diagnosis of an insulinoma is based on Whipple's triad: neuroglycopemia with a proven hypoglycemia and elevated circulating insulin levels with resolving of symptoms after normoglycemia is established (Whipple 1938, de Herder et al. 2006, Cryer et al. 2009). Some patients suffer from convulsions or abnormal behavior resulting in long neurological or psychiatric treatment before the insulinoma is diagnosed. These disabling symptoms might bear an advantage: almost 90\% of patients present with localized disease with tumors smaller than $5 \mathrm{~cm}$ restricted to the pancreas. Prognosis is excellent in these patients. Overall survival and curation rates are often near $100 \%$ after enucleation or (partial) pancreatectomy, higher than most series on non-functioning pNETs (Tsutsumi et al. 2013, Mehrabi et al. 2014).

Once metastasized, insulinomas form a unique clinical challenge. With its recurrent hypoglycemias, it causes major comorbidity and, if uncontrolled, mortality as well. In this often palliative setting, symptom control is the major treatment goal in these patients. Diazoxide is often used to prevent hypoglycemia by reducing insulin secretion through its effect on ATP-sensitive potassium channels (Altszuler et al. 1977). Fluid retention and hirsutism are the most common side effects (Gill et al. 1997). If the insulinoma expresses somatostatin receptors

Table 5 Reported survival (either hazard ratio or median survival) comparing functional and non-functional pancreatic neuroendocrine tumors.

\begin{tabular}{|c|c|c|c|c|}
\hline & $\begin{array}{l}\text { Hazard ratio for functioning pNET } \\
\qquad(95 \% \mathrm{Cl})\end{array}$ & $\begin{array}{c}\text { Median survival (functional vs } \\
\text { non-functional) }\end{array}$ & $P$ value & \\
\hline Cubilla and Hajdu (1975) & & 2.8 years vs 4.3 years & NA & $P$ value not reported \\
\hline Venkatesh et al. (1990) & & 45.2 vs 40.4 months & $>0.2$ & Surgical \\
\hline Hochwald et al. (2002) & & 152 vs 110 months & 0.61 & Surgical \\
\hline Panzuto et al. (2005) & $0.9(0.38-2.15)$ & & 0.8 & \\
\hline Ekeblad et al. (2008) & $0.63(0.48-0.83)$ & & 0.004 & $\begin{array}{l}\text { Not significant in } \\
\text { multivariate analysis }\end{array}$ \\
\hline Yang et al. (2015) & & 80.2 months vs 45.3 months & 0.005 & $\begin{array}{l}\text { Not significant in } \\
\text { multivariate analysis }\end{array}$ \\
\hline $\begin{array}{l}\text { http://erc.endocrinology-journals.org } \\
\text { DOI: } 10.1530 / \text { ERC-16-0538 }\end{array}$ & $\begin{array}{l}\text { (c) } 2017 \text { Society for Endocrinolo } \\
\text { Printed in Great Brita }\end{array}$ & Published by Bioscientifica Ltd. & & \\
\hline
\end{tabular}


lanreotide or octreotide LAR can potentially reduce insulin secretion as well. However, if somatostatin receptor-expression is low, these drugs can also increase the number of hypoglycemias by decreasing glucagon secretion, more than they decrease insulin secretion. A short clinical trial with short-acting octreotide is, therefore, recommended when starting with somatostatin analogs (de Herder et al. 2011).

PRRT with radiolabeled somatostatin has also been reported to be effective in reducing hypoglycemia in patients with metastatic insulinoma. Treatment results in long-lasting euglycemia and can stabilize tumor growth (van Schaik et al. 2011). Other effective options for metastasized insulinoma include chemotherapy (streptozotocin and 5-fluorouracil) or everolimus (Moertel et al. 1980, Kulke et al. 2009, Bernard et al. 2013).

As metastasized insulinomas are rare, no large series are available on prognosis. The few series with more than 10 patients report a median survival of approximately 2-3 years, but survival of over 30 years has been described in single patients (Danforth et al. 1984, Hirshberg et al. 2005, Starke et al. 2005). All these series have been published before PRRT or tumor-targeting therapy was available and thereby probably underestimate current prognosis as for example van Schaik and coworkers report a median progression-free survival of 27 months in five patients after treatment with PRRT, which is a vast improvement compared to these historical cohorts. Median survival of metastatic non-functioning pNET in the period before 2005 is 2-3 years as well (Solorzano et al. 2001, Wang et al. 2011, Yang et al. 2014).

So it seems that insulinomas have a better prognosis than non-functioning pNETs when resectable, but metastatic disease has not been reported to have a better survival. It remains unclear if the better prognosis of insulinomas is due to the early detection because of hypoglycemia or whether this is related to a more indolent course of disease caused by other factors like different genetic mutations in line with evidence in nonfunctioning pNETs (Sadanandam et al. 2015).

\section{Gastrinoma}

Gastrin secreted in large amounts by a gastrinoma causes severe peptic ulcer disease through acid hypersecretion and is known as the Zollinger-Ellison Syndrome (ZES) (Zollinger \& Ellison 1955). ZES is diagnosed when an inappropriate high gastrin is demonstrated, but the diagnosis is challenging because of proton-pumpinhibitors (PPIs) being widely used nowadays (Falconi et al. 2016).
Discontinuing PPIs can aid the diagnostic process, but in patients with ZES, peptic complications can rapidly arise, so this should only be done cautiously (Poitras et al. 2012). Gastrinomas are most often localized in the duodenum or the pancreas (gastrinoma triangle), but are not always found with pre-operative imaging. Fortunately, this does not influence the outcome and should not withhold patients from surgery (Alexander et al. 1998, Norton et al. 2012). A sharp decrease in peptic complications in ZES has been established since the introduction of PPIs leading to a discussion if surgery is indicated for ZES (Hirschowitz et al. 2005, Wilcox et al. 2011). Treatment strategy is also highly dependent on the presence or absence of the multiple endocrine neoplasia 1 (MEN-1) syndrome. Several studies have shown the benefit of surgical resection for sporadic gastrinoma. A large amount of patients have lymph node metastases at the time of first resection, so removal of peritumoral nodes is advised (Norton et al. 2012, Giovinazzo et al. 2013). This results in curation of approximately half of patients after surgery and an excellent 10-year survival of over $90 \%$ in patients with a localized gastrinoma, higher than non-functional pNETs (Thompson et al. 1988, Weber et al. 1995, Bilimoria et al. 2008, Norton et al. 2012). For MEN-1-associated gastrinomas, only medical treatment with PPIs can be started in most cases. Due to the multifocal nature of gastrinomas in MEN-1, curation rates are much lower in MEN-1 patients, but on the other hand, prognosis is better, also justifying an observational strategy (Weber et al. 1995, Jensen et al. 2012). Although local lymph node metastases do not seem to influence prognosis too much, survival does decrease once liver metastases occur. Then 5-year survival decreases to $30-46 \%$ with 10-year survival of $16-30 \%$ (Weber et al. 1995, Yu et al. 1999). This seems to be slightly better in MEN-1 with reported 15-year survival of over $50 \%$. Mainly when diffuse liver metastases are diagnosed survival is significantly reduced in MEN-1 (Yu et al. 1999). Then palliative treatment should be considered in the form of SSAs, PRRT with radiolabeled somatostatin analogs or sometimes debulking, always in combination with a PPI. PRRT with radiolabeled somatostatin resulted in a partial response in $45 \%$ of patients with a gastrinoma, but time to progression was shorter than that in nonfunctioning pNETs (Kwekkeboom et al. 2008, GrozinskyGlasberg et al. 2011).

So while $60 \%$ of gastrinomas are classified as being malignant because of peritumoral lymph node metastases, this is not reflected in survival. Even with only $50 \%$ cure after local resection, survival is high in the absence of liver

Published by Bioscientifica Ltd 
metastases, and in surgical cases, survival is higher than that for patients with non-functional pNETs.

\section{Glucagonoma}

Patients with a glucagonoma usually present with diabetes mellitus and typical skin lesions named necrolytic migratory erythema. Other clinical features include glossitis, anemia, weight loss and venous thrombosis (Soga \& Yakuwa 1999a). First described in 1966 by McGravan, current incidence is estimated to be 0.02-0.06 per million (McGavran et al. 1966, Vinik \& Moattari 1989, Yao et al. 2007). Tumors are localized in the pancreatic body or tail in $80 \%$ of patients and more than half of patients present with liver metastases (Soga \& Yakuwa 1999a). In line with the other pNETs, surgery should be considered for localized glucagonoma. It is of importance to correct diabetes mellitus and mineral deficiencies in the often cachectic patients. SSAs can be administered pre-operatively to aid in this process and simultaneously low-molecular-weight heparins should be administered for prevention of thrombosis (Kaltsas et al. 2004). Radical resection of the glucagonoma can result in long-lasting remission in $80-100 \%$ of patients (Soga \& Yakuwa 1999a, Chu et al. 2003).

In patients with metastatic glucagonoma treatment with SSAs results in weight increase and reduction of skin lesions (Kindmark et al. 2007, Eldor et al. 2011). Small numbers of patients have been treated with PRRT with radiolabeled somatostatin. The largest series of patients has been described by Soga and coworkers. Describing 407 cases of glucagonoma, they report a 10-year survival of $100 \%$ in localized disease (not including peri-operative mortality) and 51\% in case of metastatic glucagonoma (Soga \& Yakuwa 1999a). Other smaller series report 5-year survival of $70 \%$ for all stages of glucagonoma combined (Chu et al. 2003, Kindmark et al. 2007, Eldor et al. 2011). No direct comparison between non-functioning pNETS and glucagonomas are available.

\section{VIPoma}

The syndrome caused by hypersecretion of vasoactive intenstinal peptide (VIP) is known under multiple synonyms, namely VIPoma, Verner-Morrison syndrome, pancreatic cholera or Watery diarrhea hypokalemia achlorhydria (WDHA) syndrome. Currently VIPoma syndrome is mostly used in literature, but supplied with all these names one already knows a lot about VIPomas.
First described by Verner and Morrison in 1958, hardly all patients present with diarrhea, sometimes so severeit causes hypokalemia and metabolic acidosis through bicarbonate depletion (Verner \& Morrison 1958). The primary tumor is localized in the pancreas in $81 \%$ of patients, and these tumors behave more malignant than the approximately $20 \%$ neurogenic tumors (Soga \& Yakuwa 1999b). As one of the rarest syndromes in pNETs (estimated incidence of 0.1-0.6 per million) few large series on epidemiology and survival are available. Once again, localized disease has an excellent prognosis when resection is feasible (5 year survival 94\%), but 5-year survival declines to $60 \%$ in the presence of liver metastases (Soga \& Yakuwa 1999b). No direct comparison with non-functioning NETs is available once more, but survival seems to be grossly similar as metastatic non-functioning pNETs. If curative surgery is no longer an option treatment with SSAs can dramatically reduce stool volumes. Reduction of tumor volume, either through debulking, embolization, PRRT or radiofrequency ablation have all successfully been used in individual cases (Peng et al. 2004, Moug et al. 2006, Kwekkeboom et al. 2008).

\section{ACTH}

Ectopic ACTH secretion (EAS) is a type of Cushing's syndrome (CS), a severe endocrine disorder associated with severe morbidity and high mortality risk (Lacroix et al. 2015). In 1963, EAS was identified as a cause of CS when Liddle described a case of CS caused by a malignancy secreting ACTH (Liddle et al. 1963). It is now known to cause approximately $10-20 \%$ of CS and it is associated with pulmonary NET (small-cell lung carcinoma and carcinoid), pNET, pheochromocytoma and medullary thyroid carcinoma (Ilias et al. 2005). Typical signs and symptoms are muscle weakness, hypokalemia, body weight changes, truncal obesity, full moon face, hypertension and diabetes (Lacroix et al. 2015). EAS can often present with an aggressive form of CS, with urinary free cortisol more than 10 times elevated. EAS patients are thereby at risk of heart failure, opportunistic infection, bowel perforation and pancreatitis (Ilias et al. 2005, Isidori et al. 2006, Kamp et al. 2016). As soon as EAS is diagnosed, control of hypercortisolism should have high priority. Options include ketoconazole, metyrapone and also laparoscopic biadrenalectomy should certainly be considered in severe cases (van der Pas et al. 2012, Reincke et al. 2015). Resection of localized disease will of course cure EAS but 
should be performed preferably when hypercortisolism is controlled to prevent complications.

Due to the complications of hypercortisolism mortality is high at presentation, but thereafter, it is mainly influenced by stage and type of tumor. EAS associated with small-cell lung cancer and medullary thyroid carcinoma have the worst prognosis while occult tumors and NETs have a better prognosis (five-year survival 60-80\%) (Ilias et al. 2005). Kamp and coworkers demonstrated a worse prognosis during the first 5 years of treatment of EAS patients vs other NETs, but over the entire follow-up no significant difference was found (Kamp et al. 2016). At baseline, EAS patient had stage IV disease in significantly higher percentage but number of patients was too small to correct for stage. It does however affirm that aggressive treatment of hypercortisolism is essential, because of its high mortality rate, but when this is done successfully, survival is limited by tumor burden comparable to nonfunctioning pNETs.

\section{Conclusion}

Every hormone hypersecretory syndrome associated with NETs presents with its own clinical challenge varying from hypoglycemia to heart failure and from opportunistic infections to diarrhea. This influences prognosis in a number a ways. On the one hand, symptoms allow for detection in earlier stages but the effects of hypersecretion can increase mortality. Survival in localized functioning NETs has always been high, but survival in metastatic disease is now also increasing, mainly due to the introduction of SSAs and PRRT with radiolabeled somatostatin which both reduce secretion and tumor growth, but also targeted therapy with everolimus and sunitnib, increases PFS.

Contemporary studies in midgut NETs show no significant difference in survival between patients with the carcinoid syndrome and those without, probably as a result of SSAs and other new therapies. The worse prognosis often reported in patients with the carcinoid syndrome is probably a reflection of tumor burden and not due to the serotonin secretion.

In pNETs multiple hormonal syndromes have been described. In studies comparing functioning pNETs as a whole, they often have a better survival than the non-functional pNETs, but correction for stage and differentiation often corrects for this fact, probably explaining the difference in survival.
For individual syndromes, excellent prognosis has been reported when a radical resection is possible and then survival is better than non-functional pNETs. Mainly insulinomas and gastrinomas seem to have a better survival than non-functioning pNETs, but this comparison can only be made by comparing different populations, which makes this conclusion limited. The overall survival in patients with the other functional pNET syndromes is shorter and conclusions are difficult to make as stage and grade differ and reported numbers are often too low to reach significance. But overall, the arsenal of drugs currently available has limited mortality associated with hypersecretion and NET mortality is now mainly caused by tumor burden and no longer by hypersecretion.

\section{Declaration of interest}

W T Z, K K and R C S V A have no disclosures to report. R A F received research grants and speakers fee from Novartis. W W d $\mathrm{H}$ served on advisory boards for and received speakers fees from Ipsen and Novartis.

\section{Funding}

This research did not receive any specific grant from any funding agency in the public, commercial or not-for-profit sector.

\section{References}

Alexander HR, Fraker DL, Norton JA, Bartlett DL, Tio L, Benjamin SB, Doppman JL, Goebel SU, Serrano J, Gibril F, et al. 1998 Prospective study of somatostatin receptor scintigraphy and its effect on operative outcome in patients with Zollinger-Ellison syndrome. Annals of Surgery 228 228-238. (doi:10.1097/00000658-19980800000013)

Altszuler N, Moraru E \& Hampshire J 1977 On the mechanism of diazoxide-induced hyperglycemia. Diabetes 26 931-935. (doi:10.2337/diab.26.10.931)

Arnold R, Wilke A, Rinke A, Mayer C, Kann PH, Klose KJ, Scherag A, Hahmann M, Muller HH \& Barth P 2008 Plasma chromogranin A as marker for survival in patients with metastatic endocrine gastroenteropancreatic tumors. Clinical Gastroenterology and Hepatology 6 820-827. (doi:10.1016/j.cgh.2008.02.052)

Barclay TH \& Schapira DV 1983 Malignant tumors of the small intestine. Cancer 51 878-881. (doi:10.1002/10970142(19830301)51:5<878::AID-CNCR2820510521>3.0.CO;2-V)

Bax ND, Woods HF, Batchelor A \& Jennings M 1996 Clinical manifestations of carcinoid disease. World Journal of Surgery 20 142-146. (doi:10.1007/s002689900022)

Bernard V, Lombard-Bohas C, Taquet MC, Caroli-Bosc FX, Ruszniewski P, Niccoli P, Guimbaud R, Chougnet CN, Goichot B, Rohmer V, et al. 2013 Efficacy of everolimus in patients with metastatic insulinoma and refractory hypoglycemia. European Journal of Endocrinology 168 665-674. (doi:10.1530/EJE-12-1101)

Bhattacharyya S, Raja SG, Toumpanakis C, Caplin ME, Dreyfus GD \& Davar J 2010 Outcomes, risks and complications of cardiac surgery for carcinoid heart disease. European Journal of Cardio-Thoracic Surgery 40 168-172. (doi:10.1016/j.ejcts.2010.10.035)
(C) 2017 Society for Endocrinology Printed in Great Britain
Published by Bioscientifica Ltd 
Bilimoria KY, Tomlinson JS, Merkow RP, Stewart AK, Ko CY, Talamont MS \& Bentrem DJ 2007 Clinicopathologic features and treatment trends of pancreatic neuroendocrine tumors: analysis of 9,821 patients. Journal of Gastrointestinal Surgery 11 1460-1467. (doi:10.1007/s11605-007-0263-3)

Bilimoria KY, Talamonti MS, Tomlinson JS, Stewart AK, Winchester DP, Ko CY \& Bentrem DJ 2008 Prognostic score predicting survival after resection of pancreatic neuroendocrine tumors: analysis of 3851 patients. Annals of Surgery 247 490-500. (doi:10.1097/ SLA.0b013e31815b9cae)

Caplin ME, Pavel M \& Ruszniewski P 2014 Lanreotide in metastatic enteropancreatic neuroendocrine tumors. New England Journal of Medicine 371 1556-1557. (doi:10.1056/nejmc1409757)

Cassidy M 1930 Abdominal carcinomatosis with probable adrenal involvement. Proceedings of the Royal Society of Medicine 24 139-141.

Cassidy MA 1931 Post-mortem findings in case shown on October 10, 1930, as one of abdominal carcinomatosis with probable adrenal involvement. Proceedings of the Royal Society of Medicine 24 920-921.

Cheema A, Weber J \& Strosberg JR 2012 Incidental detection of pancreatic neuroendocrine tumors: an analysis of incidence and outcomes. Annals of Surgical Oncology 19 2932-2936. (doi:10.1245/ s10434-012-2285-7)

Chu QD, Hill HC, Douglass HO Jr, Driscoll D, Smith JL, Nava HR \& Gibbs JF 2002 Predictive factors associated with long-term survival in patients with neuroendocrine tumors of the pancreas. Annals of Surgical Oncology 9 855-862. (doi:10.1007/BF02557521)

Chu Q, Al-Kasspooles M, Smith J, Nava H, Douglass H, Driscoll D \& Gibbs J 2003 Is glucagonoma of the pancreas a curable disease? International Journal of Gastrointestinal Cancer 29 155-162. (doi:10.1385/IJGC:29:3:155)

Connolly HM, Schaff HV, Abel MD, Rubin J, Askew JW, Li Z, Inda JJ Luis SA, Nishimura RA \& Pellikka PA 2015 Early and late outcomes of surgical treatment in carcinoid heart disease. Journal of the American College of Cardiology 66 2189-2196. (doi:10.1016/j. jacc.2015.09.014)

Crippa S, Partelli S, Zamboni G, Scarpa A, Tamburrino D, Bassi C, Pederzoli P \& Falconi M 2014 Incidental diagnosis as prognostic factor in different tumor stages of nonfunctioning pancreatic endocrine tumors. Surgery 155 145-153. (doi:10.1016/j. surg.2013.08.002)

Cryer PE, Axelrod L, Grossman AB, Heller SR, Montori VM, Seaquist ER, Service FJ \& Endocrine S 2009 Evaluation and management of adult hypoglycemic disorders: an Endocrine Society Clinical Practice Guideline. Journal of Clinical Endocrinology and Metabolism 94 709-728. (doi:10.1210/jc.2008-1410)

Cubilla AL \& Hajdu SI 1975 Islet cell carcinoma of the pancreas. Archives of Pathology 99 204-207.

Danforth DN Jr, Gorden P \& Brennan MF 1984 Metastatic insulinsecreting carcinoma of the pancreas: clinical course and the role of surgery. Surgery 96 1027-1037.

de Herder WW, Niederle B, Scoazec JY, Pauwels S, Kloppel G, Falconi M, Kwekkeboom DJ, Oberg K, Eriksson B, Wiedenmann B, et al. 2006 Well-differentiated pancreatic tumor/carcinoma: insulinoma. Neuroendocrinology 84 183-188. (doi:10.1159/000098010)

de Herder WW, van Schaik E, Kwekkeboom D \& Feelders RA 2011 New therapeutic options for metastatic malignant insulinomas. Clinical Endocrinology 75 277-284. (doi:10.1111/j.1365-2265.2011.04145.x)

Edwards NC, Yuan M, Nolan O, Pawade TA, Oelofse T, Singh H, Mehrzad H, Zia Z, Geh JI, Palmer DH, et al. 2016 Effect of valvular surgery in carcinoid heart disease: an observational cohort study. Journal of Clinical Endocrinology and Metabolism 101 183-190. (doi:10.1210/jc.2015-3295)

Ekeblad S, Skogseid B, Dunder K, Oberg K \& Eriksson B 2008 Prognostic factors and survival in 324 patients with pancreatic endocrine tumor treated at a single institution. Clinical Cancer Research 14 7798-7803. (doi:10.1158/1078-0432.CCR-08-0734)
Eldor R, Glaser B, Fraenkel M, Doviner V, Salmon A \& Gross DJ 2011 Glucagonoma and the glucagonoma syndrome - cumulative experience with an elusive endocrine tumour. Clinical Endocrinology 74 593-598. (doi:10.1111/j.1365-2265.2011.03967.x)

Ellis L, Shale MJ \& Coleman MP 2010 Carcinoid tumors of the gastrointestinal tract: trends in incidence in England since 1971. American Journal of Gastroenterology 105 2563-2569. (doi:10.1038/ ajg.2010.341)

Fajans SS \& Vinik AI 1989 Insulin-producing islet cell tumors. Endocrinology Metabolism Clinics of North America 18 45-74.

Falconi M, Eriksson B, Kaltsas G, Bartsch DK, Capdevila J, Caplin M, Kos-Kudla B, Kwekkeboom D, Rindi G, Kloppel G, et al. 2016 ENETS consensus guidelines update for the management of patients with functional pancreatic neuroendocrine tumors and non-functional pancreatic neuroendocrine tumors. Neuroendocrinology 103 153-171. (doi:10.1159/000443171)

Formica V, Wotherspoon A, Cunningham D, Norman AR, Sirohi B, Oates J \& Chong G 2007 The prognostic role of WHO classification, urinary 5-hydroxyindoleacetic acid and liver function tests in metastatic neuroendocrine carcinomas of the gastroenteropancreatic tract. British Journal of Cancer 96 1178-1182. (doi:10.1038/sj. bjc.6603699)

Gao C, Fu X, Pan Y \& Li Q 2010 Surgical treatment of pancreatic neuroendocrine tumors: report of 112 cases. Digestive Surgery $\mathbf{2 7}$ 197-204. (doi:10.1159/000253871)

Gill GV, Rauf O \& MacFarlane IA 1997 Diazoxide treatment for insulinoma: a national UK survey. Postgraduate Medical Journal 73 640-641. (doi:10.1136/pgmj.73.864.640)

Giovinazzo F, Butturini G, Monsellato D, Malleo G, Marchegiani G \& Bassi C 2013 Lymph nodes metastasis and recurrences justify an aggressive treatment of gastrinoma. Updates in Surgery 65 19-24. (doi:10.1007/s13304-013-0201-8)

Grozinsky-Glasberg S, Barak D, Fraenkel M, Walter MA, Mueller-Brand J, Eckstein J, Applebaum L, Shimon I \& Gross DJ 2011 Peptide receptor radioligand therapy is an effective treatment for the long-term stabilization of malignant gastrinomas. Cancer 117 1377-1385. (doi:10.1002/cncr.25646)

Grozinsky-Glasberg S, Grossman AB \& Gross DJ 2015 Carcinoid heart disease: from pathophysiology to treatment - 'something in the way it moves'. Neuroendocrinology 101 263-273. (doi:10.1159/000381930)

Halfdanarson TR, Rabe KG, Rubin J \& Petersen GM 2008 Pancreatic neuroendocrine tumors (PNETs): incidence, prognosis and recent trend toward improved survival. Annals of Oncology 19 1727-1733. (doi:10.1093/annonc/mdn351)

Halperin DM, Shen C, Dasari A, Xu Y, Chu Y, Zhou S, Shih YT \& Yao JC 2017 Frequency of carcinoid syndrome at neuroendocrine tumour diagnosis: a population-based study. Lancet Oncology 18 525-553.

Han X, Zhang C, Tang M, Xu X, Liu L, Ji Y, Pan B \& Lou W 2015 The value of serum chromogranin $\mathrm{A}$ as a predictor of tumor burden, therapeutic response, and nomogram-based survival in wellmoderate nonfunctional pancreatic neuroendocrine tumors with liver metastases. European Journal of Gastroenterology and Hepatology 27 527-535. (doi:10.1097/MEG.0000000000000332)

Hirschowitz BI, Simmons J \& Mohnen J 2005 Clinical outcome using lansoprazole in acid hypersecretors with and without ZollingerEllison syndrome: a 13-year prospective study. Clinical Gastroenterology and Hepatology 3 39-48. (doi:10.1016/S15423565(04)00606-8)

Hirshberg B, Cochran C, Skarulis MC, Libutti SK, Alexander HR, Wood BJ, Chang R, Kleiner DE \& Gorden P 2005 Malignant insulinoma: spectrum of unusual clinical features. Cancer 104 264-272. (doi:10.1002/cncr.21179)

Hochwald SN, Zee S, Conlon KC, Colleoni R, Louie O, Brennan MF \& Klimstra DS 2002 Prognostic factors in pancreatic endocrine neoplasms: an analysis of 136 cases with a proposal for low-grade

Published by Bioscientifica Ltc. 
and intermediate-grade groups. Journal of Clinical Oncology 20 2633-2642. (doi:10.1200/JCO.2002.10.030)

Ilias I, Torpy DJ, Pacak K, Mullen N, Wesley RA \& Nieman LK 2005 Cushing's syndrome due to ectopic corticotropin secretion: twenty years' experience at the National Institutes of Health. Journal of Clinical Endocrinology and Metabolism 90 4955-4962. (doi:10.1210/ jc.2004-2527)

Isidori AM, Kaltsas GA, Pozza C, Frajese V, Newell-Price J, Reznek RH, Jenkins PJ, Monson JP, Grossman AB \& Besser GM 2006 The ectopic adrenocorticotropin syndrome: clinical features, diagnosis, management, and long-term follow-up. Journal of Clinical Endocrinology and Metabolism 91 371-377. (doi:10.1210/jc.2005-1542)

Jann H, Roll S, Couvelard A, Hentic O, Pavel M, Muller-Nordhorn J, Koch M, Rocken C, Rindi G, Ruszniewski P, et al. 2011 Neuroendocrine tumors of midgut and hindgut origin: tumor-nodemetastasis classification determines clinical outcome. Cancer 117 3332-3341. (doi:10.1002/cncr.25855)

Janson ET, Holmberg L, Stridsberg M, Eriksson B, Theodorsson E, Wilander E \& Oberg K 1997 Carcinoid tumors: analysis of prognostic factors and survival in 301 patients from a referral center. Annals of Oncology 8 685-690. (doi:10.1023/A:1008215730767)

Jarufe NP, Coldham C, Orug T, Mayer AD, Mirza DF, Buckels JA \& Bramhall SR 2005 Neuroendocrine tumours of the pancreas: predictors of survival after surgical treatment. Digestive Surgery 22 157-162. (doi:10.1159/000087148)

Jensen RT, Cadiot G, Brandi ML, de Herder WW, Kaltsas G, Komminoth P, Scoazec JY, Salazar R, Sauvanet A \& Kianmanesh R 2012 ENETS consensus guidelines for the management of patients with digestive neuroendocrine neoplasms: functional pancreatic endocrine tumor syndromes. Neuroendocrinology 95 98-119. (doi:10.1159/000335591)

Kaltsas GA, Besser GM \& Grossman AB 2004 The diagnosis and medical management of advanced neuroendocrine tumors. Endocrine Reviews 25 458-511. (doi:10.1210/er.2003-0014)

Kam BLR, Teunissen JJM, Krenning EP, de Herder WW, Khan S, van Vliet EI \& Kwekkeboom DJ 2012 Lutetium-labelled peptides for therapy of neuroendocrine tumours. European Journal of Nuclear Medicine and Molecular Imaging 39 (Supplement 1) 103-112. (doi:10.1007/s00259. 011-2039-y)

Kamp K, Alwani RA, Korpershoek E, Franssen GJ, de Herder WW \& Feelders RA 2016 Prevalence and clinical features of the ectopic ACTH syndrome in patients with gastroenteropancreatic and thoracic neuroendocrine tumors. European Journal of Endocrinology 174 271-280. (doi:10.1530/EJE-15-0968)

Kidd M, Modlin IM, Bodei L \& Drozdov I 2015 Decoding the molecular and mutational ambiguities of gastroenteropancreatic neuroendocrine neoplasm pathobiology. Cellular and Molecular Gastroenterology and Hepatology 1 131-153. (doi:10.1016/j. jcmgh.2014.12.008)

Kindmark H, Sundin A, Granberg D, Dunder K, Skogseid B, Janson ET, Welin S, Oberg K \& Eriksson B 2007 Endocrine pancreatic tumors with glucagon hypersecretion: a retrospective study of 23 cases during 20 years. Medical Oncology 24 330-337. (doi:10.1007/s12032007-0011-2)

Klimstra DS, Modlin IR, Coppola D, Lloyd RV \& Suster S 2010 The pathologic classification of neuroendocrine tumors: a review of nomenclature, grading, and staging systems. Pancreas 39 707-712. (doi:10.1097/MPA.0b013e3181ec124e)

Kulke MH, Bergsland EK \& Yao JC 2009 Glycemic control in patients with insulinoma treated with everolimus. New England Journal of Medicine 360 195-197. (doi:10.1056/NEJMc0806740)

Kvols LK, Moertel CG, O'Connell MJ, Schutt AJ, Rubin J \& Hahn RG 1986 Treatment of the malignant carcinoid syndrome. Evaluation of a long-acting somatostatin analogue. New England Journal of Medicine 315 663-666. (doi:10.1056/NEJM198609113151102)
Kwekkeboom DJ, de Herder WW, Kam BL, van Eijck CH, van Essen M, Kooij PP, Feelders RA, van Aken MO \& Krenning EP 2008 Treatment with the radiolabeled somatostatin analog [177 Lu-DOTA 0,Tyr3]octreotate: toxicity, efficacy, and survival. Journal of Clinical Oncology 26 2124-2130. (doi:10.1200/ JCO.2007.15.2553)

La Rosa S, Franzi F, Albarello L, Schmitt A, Bernasconi B, Tibiletti MG, Finzi G, Placidi C, Perren A \& Capella C 2011 Serotonin-producing enterochromaffin cell tumors of the pancreas: clinicopathologic study of 15 cases and comparison with intestinal enterochromaffin cell tumors. Pancreas 40 883-895. (doi:10.1097/ MPA.0b013e31822041a9)

Lacroix A, Feelders RA, Stratakis CA \& Nieman LK 2015 Cushing's syndrome. Lancet 386 913-927. (doi:10.1016/S01406736(14)61375-1)

Landerholm K, Falkmer S \& Jarhult J 2010 Epidemiology of small bowel carcinoids in a defined population. World Journal of Surgery 34 1500-1505. (doi:10.1007/s00268-010-0519-z)

Liddle GW, Island DP, Ney RL, Nicholson WE \& Shimizu N 1963 Nonpituitary neoplasms and Cushing's syndrome. Ectopic 'adrenocorticotropin' produced by nonpituitary neoplasms as a cause of Cushing's syndrome. Archives of Internal Medicine 111 471-475. (doi:10.1001/archinte.1963.03620280071011)

Makridis C, Ekbom A, Bring J, Rastad J, Juhlin C, Oberg K \& Akerstrom G 1997 Survival and daily physical activity in patients treated for advanced midgut carcinoid tumors. Surgery 122 1075-1082. (doi:10.1016/S0039-6060(97)90211-7)

Martin-Perez E, Capdevila J, Castellano D, Jimenez-Fonseca P, Salazar R, Beguiristain-Gomez A, Alonso-Orduna V, Martinez Del Prado P, Villabona-Artero C, Diaz-Perez JA, et al. 2013 Prognostic factors and long-term outcome of pancreatic neuroendocrine neoplasms: Ki-67 index shows a greater impact on survival than disease stage. The large experience of the Spanish National Tumor Registry (RGETNE). Neuroendocrinology 98 156-168. (doi:10.1159/000355152)

McGavran MH, Unger RH, Recant L, Polk HC, Kilo C \& Levin ME 1966 A glucagon-secreting alpha-cell carcinoma of the pancreas. New England Journal of Medicine 274 1408-1413. (doi:10.1056/ NEJM196606232742503)

Mehrabi A, Fischer L, Hafezi M, Dirlewanger A, Grenacher L, Diener MK, Fonouni H, Golriz M, Garoussi C, Fard N, et al. 2014 A systematic review of localization, surgical treatment options, and outcome of insulinoma. Pancreas 43 675-686. (doi:10.1097/ MPA.0000000000000110)

Modlin IM, Lye KD \& Kidd M 2003 A 5-decade analysis of 13,715 carcinoid tumors. Cancer 97 934-959. (doi:10.1002/cncr.11105)

Modlin IM, Shapiro MD \& Kidd M 2005 An analysis of rare carcinoid tumors: clarifying these clinical conundrums. World Journal of Surgery 29 92-101. (doi:10.1007/s00268-004-7443-z)

Modlin IM, Pavel M, Kidd M \& Gustafsson BI 2010 Review article: somatostatin analogues in the treatment of gastroenteropancreatic neuroendocrine (carcinoid) tumours. Alimentary Pharmacology and Therapeutics 31 169-188.

Moertel CG, Hanley JA \& Johnson LA 1980 Streptozocin alone compared with streptozocin plus fluorouracil in the treatment of advanced islet-cell carcinoma. New England Journal of Medicine $\mathbf{3 0 3}$ 1189-1194. (doi:10.1056/NEJM198011203032101)

Mokhles P, van Herwerden LA, de Jong PL, de Herder WW, Siregar S, Constantinescu AA, van Domburg RT \& Roos-Hesselink JW 2012 Carcinoid heart disease: outcomes after surgical valve replacement. European Journal of Cardio-Thoracic Surgery 41 1278-1283. (doi:10.1093/ejcts/ezr227)

Moller JE, Pellikka PA, Bernheim AM, Schaff HV, Rubin J \& Connolly HM 2005 Prognosis of carcinoid heart disease: analysis of 200 cases http://erc.endocrinology-journals.org

DOI: $10.1530 /$ ERC-16-0538
๑ 2017 Society for Endocrinology Printed in Great Britain
Published by Bioscientifica Ltd. 
over two decades. Circulation 112 3320-3327. (doi:10.1161/ CIRCULATIONAHA.105.553750)

Moug SJ, Leen E, Horgan PG \& Imrie CW 2006 Radiofrequency ablation has a valuable therapeutic role in metastatic VIPoma. Pancreatology 6 155-159. (doi:10.1159/000090257)

Niederle MB, Hackl M, Kaserer K \& Niederle B 2010 Gastroenteropancreatic neuroendocrine tumours: the current incidence and staging based on the WHO and European Neuroendocrine Tumour Society classification: an analysis based on prospectively collected parameters. Endocrine-Related Cancer 17 909-918. (doi:10.1677/ERC-10-0152)

Norheim I, Oberg K, Theodorsson-Norheim E, Lindgren PG, Lundqvist G, Magnusson A, Wide L \& Wilander E 1987 Malignant carcinoid tumors. An analysis of 103 patients with regard to tumor localization, hormone production, and survival. Annals of Surgery 206 115-125. (doi:10.1097/00000658-198708000-00001)

Norton JA, Fraker DL, Alexander HR \& Jensen RT 2012 Value of surgery in patients with negative imaging and sporadic Zollinger-Ellison syndrome. Annals of Surgery 256 509-517. (doi:10.1097/ SLA.0b013e318265f08d)

O'Toole D, Grossman A, Gross D, Delle Fave G, Barkmanova J, O'Connor J, Pape UF, Plockinger U, Mallorca Consensus Conference Participants \& European Neuroendocrine Tumor Society 2009 ENETS consensus guidelines for the standards of care in neuroendocrine tumors: biochemical markers. Neuroendocrinology 90 194-202. (doi:10.1159/000225948)

Oberndorfer S 1907 Karzinoïde tumoren des dunndarms. Frankfurter Zeitschrift für Pathologie 1 426-429.

Page IH 1954 Serotonin (5-hydroxytryptamine). Physiological Reviews 34 563-588.

Panzuto F, Nasoni S, Falconi M, Corleto VD, Capurso G, Cassetta S, Di Fonzo M, Tornatore V, Milione M, Angeletti S, et al. 2005 Prognostic factors and survival in endocrine tumor patients: comparison between gastrointestinal and pancreatic localization. EndocrineRelated Cancer 12 1083-1092. (doi:10.1677/erc.1.01017)

Pape UF, Berndt U, Muller-Nordhorn J, Bohmig M, Roll S, Koch M, Willich SN \& Wiedenmann B 2008 Prognostic factors of long-term outcome in gastroenteropancreatic neuroendocrine tumours. Endocrine-Related Cancer 15 1083-1097. (doi:10.1677/ERC-08-0017)

Partelli S, Inama M, Rinke A, Begum N, Valente R, Fendrich V, Tamburrino D, Keck T, Caplin ME, Bartsch D, et al. 2015 Long-term outcomes of surgical management of pancreatic neuroendocrine tumors with synchronous liver metastases. Neuroendocrinology 102 68-76. (doi:10.1159/000431379)

Pavel ME, Hainsworth JD, Baudin E, Peeters M, Horsch D, Winkler RE, Klimovsky J, Lebwohl D, Jehl V, Wolin EM, et al. 2011 Everolimus plus octreotide long-acting repeatable for the treatment of advanced neuroendocrine tumours associated with carcinoid syndrome (RADIANT-2): a randomised, placebo-controlled, phase 3 study. Lancet 378 2005-2012. (doi:10.1016/S0140-6736(11)61742-X)

Pavel M, Horsch D, Caplin M, Ramage J, Seufferlein T, Valle J, Banks P, Lapuerta P, Sands A, Zambrowicz B, et al. 2015 Telotristat etiprate for carcinoid syndrome: a single-arm, multicenter trial. Journal of Clinical Endocrinology and Metabolism 100 1511-1519. (doi:10.1210/ jc.2014-2247)

Pavel M, O'Toole D, Costa F, Capdevila J, Gross D, Kianmanesh R, Krenning E, Knigge U, Salazar R, Pape UF, et al. 2016 ENETS consensus guidelines update for the management of distant metastatic disease of intestinal, pancreatic, bronchial neuroendocrine neoplasms (NEN) and NEN of unknown primary site. Neuroendocrinology 103 172-185. (doi:10.1159/000443167)

Peng SY, Li JT, Liu YB, Fang HQ, Wu YL, Peng CH, Wang XB \& Qian HR 2004 Diagnosis and treatment of VIPoma in China: (case report and 31 cases review) diagnosis and treatment of VIPoma. Pancreas $\mathbf{2 8}$ 93-97. (doi:10.1097/00006676-200401000-00015)
Phan GQ, Yeo CJ, Hruban RH, Littemoe KD, Pitt HA \& Cameron JL 1998 Surgical experience with pancreatic and peripancreatic neuroendocrine tumors: review of 125 patients. Journal of Gastrointestinal Surgery 2 473-482. (doi:10.1016/S1091255X(98)80039-5)

Poitras P, Gingras MH \& Rehfeld JF 2012 The Zollinger-Ellison syndrome: dangers and consequences of interrupting antisecretory treatment. Clinical Gastroenterology and Hepatology 10 199-202. (doi:10.1016/j.cgh.2011.08.012)

Postma C 1927 Een geval van haemangioma planum extensum. Nederlands Tijdschrift voor Geneeskunde 71 1842-1846.

Quaedvlieg PF, Visser O, Lamers CB, Janssen-Heijen ML \& Taal BG 2001 Epidemiology and survival in patients with carcinoid disease in The Netherlands. An epidemiological study with 2391 patients. Annals of Oncology 12 1295-1300. (doi:10.1023/A:1012272314550)

Raymond E, Dahan L, Raoul JL, Bang YJ, Borbath I, Lombard-Bohas C, Valle J, Metrakos P, Smith D, Vinik A, et al. 2011 Sunitinib malate for the treatment of pancreatic neuroendocrine tumors. New England Journal of Medicine 364 501-513. (doi:10.1056/NEJMoa1003825)

Reincke M, Ritzel K, Osswald A, Berr C, Stalla G, Hallfeldt K, Reisch N, Schopohl J \& Beuschlein F 2015 A critical reappraisal of bilateral adrenalectomy for ACTH-dependent Cushing's syndrome. European Journal of Endocrinology 173 M23-M32. (doi:10.1530/EJE-15-0265)

Rinke A, Muller HH, Schade-Brittinger C, Klose KJ, Barth P, Wied M, Mayer C, Aminossadati B, Pape UF, Blaker M, et al. 2009 Placebocontrolled, double-blind, prospective, randomized study on the effect of octreotide LAR in the control of tumor growth in patients with metastatic neuroendocrine midgut tumors: a report from the PROMID Study Group. Journal of Clinical Oncology 27 4656-4663. (doi:10.1200/JCO.2009.22.8510)

Robiolio PA, Rigolin VH, Harrison JK, Lowe JE, Moore JO, Bashore TM \& Feldman JM 1995 Predictors of outcome of tricuspid valve replacement in carcinoid heart disease. American Journal of Cardiology 75 485-488. (doi:10.1016/S0002-9149(99)80586-4)

Sadanandam A, Wullschleger S, Lyssiotis CA, Grotzinger C, Barbi S, Bersani S, Korner J, Wafy I, Mafficini A, Lawlor RT, et al. 2015 A cross-species analysis in pancreatic neuroendocrine tumors reveals molecular subtypes with distinctive clinical, metastatic, developmental, and metabolic characteristics. Cancer Discovery 5 1296-1313. (doi:10.1158/2159-8290.CD-15-0068)

Sadot E, Reidy-Lagunes DL, Tang LH, Do RK, Gonen M, D'Angelica MI DeMatteo RP, Kingham TP, Groot Koerkamp B, Untch BR, et al. 2016 Observation versus resection for small asymptomatic pancreatic neuroendocrine tumors: a matched case-control study. Annals of Surgical Oncology 23 1361-1370. (doi:10.1245/s10434-015-4986-1)

Sarmiento JM, Farnell MB, Que FG \& Nagorney DM 2002 Pancreaticoduodenectomy for islet cell tumors of the head of the pancreas: long-term survival analysis. World Journal of Surgery 26 1267-1271. (doi:10.1007/s00268-002-6714-9)

Scholte A 1931 Ein fall von angioma teleangiectaticum cutis mit chronischer endocarditis und malignem dünnedarmcarcinoid. Beitrage Zur Pathologischen Anatomie 86 440-443.

Seregni E, Maccauro M, Chiesa C, Mariani L, Pascali C, Mazzaferro V, De Braud F, Buzzoni R, Milione M, Lorenzoni A, et al. 2013 Treatment with tandem [90Y]DOTA-TATE and [177Lu]DOTA-TATE of neuroendocrine tumours refractory to conventional therapy. European Journal of Nuclear Medicine and Molecular Imaging 41 223-230. (doi:10.1007/s00259-013-2578-5)

Soga J 2003 Carcinoids and their variant endocrinomas. An analysis of 11842 reported cases. Journal of Experimental and Clinical Cancer Research 22 517-530.

Soga J 2005 Carcinoids of the pancreas: an analysis of 156 cases. Cancer 104 1180-1187. (doi:10.1002/cncr.21291)

Soga J \& Yakuwa Y 1999a Glucagonomas/diabetico-dermatogenic syndrome (DDS): a statistical evaluation of 407 reported cases. http://erc.endocrinology-journals.org

DOI: 10.1530/ERC-16-0538
(C) 2017 Society for Endocrinology Printed in Great Britain
Published by Bioscientifica Ltd. 
Journal of Hepato-Biliary-Pancreatic Surgery 5 312-319. (doi:10.1007/ s005340050052)

Soga J \& Yakuwa Y 1999b Vipoma/diarrheogenic syndrome: a statistical evaluation of 241 reported cases. Journal of Experimental and Clinical Cancer Research 17 389-400.

Solorzano CC, Lee JE, Pisters PW, Vauthey JN, Ayers GD, Jean ME, Gagel RF, Ajani JA, Wolff RA \& Evans DB 2001 Nonfunctioning islet cell carcinoma of the pancreas: survival results in a contemporary series of 163 patients. Surgery 130 1078-1085. (doi:10.1067/ msy.2001.118367)

Starke A, Saddig C, Mansfeld L, Koester R, Tschahargane C, Czygan P \& Goretzki P 2005 Malignant metastatic insulinoma-postoperative treatment and follow-up. World Journal of Surgery 29 789-793. (doi:10.1007/s00268-005-7743-y)

Stefanini P, Carboni M, Patrassi N \& Basoli A 1974 Hypoglycemia and insular hyperplasia: review of 148 cases. Annals of Surgery $\mathbf{1 8 0}$ 130-135. (doi:10.1097/00000658-197407000-00020)

Strosberg J, El-Haddad G, Wolin E, Hendifar A, Yao J, Chasen B, Mittra E, Kunz PL, Kulke MH, Jacene H, et al. 2017 Phase 3 trial of 177Lu-dotatate for midgut neuroendocrine tumors. New England Journal of Medicine 376 125-135. (doi:10.1056/NEJMoa1607427)

Tellez MR, Mamikunian G, O'Dorisio TM, Vinik AI \& Woltering EA 2013 A single fasting plasma 5-HIAA value correlates with 24-hour urinary 5 -HIAA values and other biomarkers in midgut neuroendocrine tumors (NETs). Pancreas 42 405-410. (doi:10.1097/ MPA.0b013e318271c0d5)

Thompson GB, van Heerden JA, Grant CS, Carney JA \& Ilstrup DM 1988 Islet cell carcinomas of the pancreas: a twenty-year experience. Surgery 104 1011-1017.

Thorson A, Biorck G, Bjorkman G \& Waldenstrom J 1954 Malignant carcinoid of the small intestine with metastases to the liver, valvular disease of the right side of the heart (pulmonary stenosis and tricuspid regurgitation without septal defects), peripheral vasomotor symptoms, bronchoconstriction, and an unusual type of cyanosis; a clinical and pathologic syndrome. American Heart Journal 47 795-817. (doi:10.1016/0002-8703(54)90152-0)

Tsutsumi K, Ohtsuka T, Fujino M, Nakashima H, Aishima S, Ueda J, Takahata S, Nakamura M, Oda Y \& Tanaka M 2013 Analysis of risk factors for recurrence after curative resection of well-differentiated pancreatic neuroendocrine tumors based on the new grading classification. Journal of Hepato-Biliary-Pancreatic Surgery 21 418-425. (doi:10.1002/jhbp.47)

Turner GB, Johnston BT, McCance DR, McGinty A, Watson RG, Patterson CC \& Ardill JE 2006 Circulating markers of prognosis and response to treatment in patients with midgut carcinoid tumours. Gut 55 1586-1591. (doi:10.1136/gut.2006.092320)

Vagefi PA, Razo O, Deshpande V, McGrath DJ, Lauwers GY, Thayer SP, Warshaw AL \& Fernandez-Del Castillo C 2007 Evolving patterns in the detection and outcomes of pancreatic neuroendocrine neoplasms: the Massachusetts General Hospital experience from 1977 to 2005. Archives of Surgery 142 347-354. (doi:10.1001/ archsurg.142.4.347)

van Adrichem RC, Kamp K, Vandamme T, Peeters M, Feelders RA \& de Herder WW 2015 Serum neuron-specific enolase level is an independent predictor of overall survival in patients with gastroenteropancreatic neuroendocrine tumors. Annals of Oncology.

van der Horst-Schrivers AN, Post WJ, Kema IP, Links TP, Willemse PH, Wymenga AN \& de Vries EG 2007 Persistent low urinary excretion of 5-HIAA is a marker for favourable survival during follow-up in patients with disseminated midgut carcinoid tumours. European Journal of Cancer 43 2651-2657. (doi:10.1016/j. ejca.2007.07.025)

van der Pas R, de Bruin C, Leebeek FW, de Maat MP, Rijken DC, Pereira AM, Romijn JA, Netea-Maier RT, Hermus AR, Zelissen PM, et al. 2012 The hypercoagulable state in Cushing's disease is associated with increased levels of procoagulant factors and impaired fibrinolysis, but is not reversible after short-term biochemical remission induced by medical therapy. Journal of Clinical Endocrinology and Metabolism 97 1303-1310. (doi:10.1210/jc.2011-2753)

van der Zwan WA, Bodei L, Mueller-Brand J, de Herder WW, Kvols LK \& Kwekkeboom DJ 2015 GEPNETs update: radionuclide therapy in neuroendocrine tumors. European Journal of Endocrinology 172 R1-8.

van Schaik E, van Vliet EI, Feelders RA, Krenning EP, Khan S, Kamp K, Valkema R, van Nederveen FH, Teunissen JJ, Kwekkeboom DJ, et al. 2011 Improved control of severe hypoglycemia in patients with malignant insulinomas by peptide receptor radionuclide therapy. Journal of Clinical Endocrinology and Metabolism 96 3381-3389. (doi:10.1210/jc.2011-1563)

Venkatesh S, Ordonez NG, Ajani J, Schultz PN, Hickey RC, Johnston DA \& Samaan NA 1990 Islet cell carcinoma of the pancreas. A study of 98 patients. Cancer 65 354-357. (doi:10.1002/1097-

0142(19900115)65:2<354::AID-CNCR2820650229>3.0.CO;2-N)

Verner JV \& Morrison AB 1958 Islet cell tumor and a syndrome of refractory watery diarrhea and hypokalemia. American Journal of Medicine 25 374-380. (doi:10.1016/0002-9343(58)90075-5)

Vinik AI \& Moattari AR 1989 Treatment of endocrine tumors of the pancreas. Endocrinology Metabolism Clinics of North America 18 483-518.

Wang SE, Su CH, Kuo YJ, Shyr YM, Li AF, Chen TH, Wu CW \& Lee CH 2011 Comparison of functional and nonfunctional neuroendocrine tumors in the pancreas and peripancreatic region. Pancreas $\mathbf{4 0}$ 253-259. (doi:10.1097/MPA.0b013e3181f94cc4)

Weber HC, Venzon DJ, Lin JT, Fishbein VA, Orbuch M, Strader DB, Gibril F, Metz DC, Fraker DL, Norton JA, et al. 1995 Determinants of metastatic rate and survival in patients with Zollinger-Ellison syndrome: a prospective long-term study. Gastroenterology 108 1637-1649. (doi:10.1016/0016-5085(95)90124-8)

Whipple A 1938 The surgical therapy of hyperinsulinism. Journal International De Chirurgie 3 237-276.

Wilcox CM, Seay T, Arcury JT, Mohnen J \& Hirschowitz BI 2011 Zollinger-Ellison syndrome: presentation, response to therapy, and outcome. Digestive and Liver Disease 43 439-443. (doi:10.1016/j. dld.2010.11.007)

Wilder RM, Allan FN, Power MH \& Robertson HE 1927 Carcinoma of the islands of the pancreas: hyperinsulinism and hypoglycemia. Journal of the American Medical Association 89 348-355. (doi:10.1001/ jama.1927.02690050014007)

Yang M, Tian BL, Zhang Y, Su AP, Yue PJ, Xu S \& Wang L 2014 Evaluation of the World Health Organization 2010 grading system in surgical outcome and prognosis of pancreatic neuroendocrine tumors. Pancreas 43 1003-1008. (doi:10.1097/ MPA.0000000000000153)

Yang M, Zeng L, Zhang Y, Wang WG, Wang L, Ke NW, Liu XB \& Tian BL 2015 TNM staging of pancreatic neuroendocrine tumors: an observational analysis and comparison by both AJCC and ENETS systems from 1 single institution. Medicine 94 e660. (doi:10.1097/ MD.0000000000000660)

Yao JC, Eisner MP, Leary C, Dagohoy C, Phan A, Rashid A, Hassan M \& Evans DB 2007 Population-based study of islet cell carcinoma. Annals of Surgical Oncology 14 3492-3500. (doi:10.1245/ s10434-007-9566-6)

Yao JC, Hassan M, Phan A, Dagohoy C, Leary C, Mares JE, Abdalla EK, Fleming JB, Vauthey JN, Rashid A, et al. 2008 One hundred years after 'carcinoid': epidemiology of and prognostic factors for neuroendocrine tumors in 35,825 cases in the United States. Journal of Clinical Oncology 26 3063-3072. (doi:10.1200/ JCO.2007.15.4377)

Yao JC, Fazio N, Singh S, Buzzoni R, Carnaghi C, Wolin E, Tomasek J, Raderer M, Lahner H, Voi M, et al. 2016 Everolimus for the treatment of advanced, non-functional neuroendocrine tumours of http://erc.endocrinology-journals.org

DOI: 10.1530/ERC-16-0538
(C) 2017 Society for Endocrinology Printed in Great Britain
Published by Bioscientifica Ltd 
the lung or gastrointestinal tract (RADIANT-4): a randomised, placebo-controlled, phase 3 study. Lancet 387 968-977. (doi:10.1016/ S0140-6736(15)00817-X)

Yu F, Venzon DJ, Serrano J, Goebel SU, Doppman JL, Gibril F \& Jensen RT 1999 Prospective study of the clinical course, prognostic factors, causes of death, and survival in patients with long-standing Zollinger-Ellison syndrome. Journal of Clinical Oncology 17 615-630. (doi:10.1200/JCO.1999.17.2.615)

Zandee W, Kamp K, van Adrichem RC, Feelders RA \& de Herder W 2016 Limited value for urinary 5-HIAA excretion as prognostic marker in gastrointestinal neuroendocrine tumors. European Journal of Endocrinology 175 361-366. (doi:10.1530/EJE-16-0392)

Zandee WT, van Adrichem RCS, Kamp K, Feelders RA, van Velthuysen MF \& de Herder WW 2017 Incidence and prognostic value of serotonin secretion in pancreatic neuroendocrine tumours. Clinical Endocrinology. (epub ahead of print)

Zollinger RM Jr 1986 Primary neoplasms of the small intestine. American Journal of Surgery 151 654-658. (doi:10.1016/00029610(86)90035-8)

Zollinger RM \& Ellison EH 1955 Primary peptic ulcerations of the jejunum associated with islet cell tumors of the pancreas. Annals of Surgery 142 709-723; discussion 724-708. (doi:10.1097/00000658195510000-00015)

Zuetenhorst JM, Korse CM, Bonfrer JM, Peter E, Lamers CB \& Taal BG 2004 Daily cyclic changes in the urinary excretion of 5-hydroxyindoleacetic acid in patients with carcinoid tumors. Clinical Chemistry 50 1634-1639. (doi:10.1373/ clinchem.2004.032151)

Received in final form 6 May 2017

Accepted 8 May 2017

Accepted Preprint published online 8 May 2017
Published by Bioscientifica Ltd. 